\title{
Synthesis and biological evaluation of platinum complexes of highly functionalized aroylaminocarbo- $N$-thioyl prolinate containing tetrahydropyrrolo[3,4-c]pyrrole-1,3(2H,3aH)-dione moieties
}

\author{
Samet Belveren, ${ }^{[a]}$ Samet Poyraz, ${ }^{[a]}$ Christopher M. Pask, ${ }^{[b]}$ Mahmut Ülger, ${ }^{[c]}$ José M. Sansano*[d] and \\ H. Ali Dondas, ${ }^{*[a]}$ \\ Dedication ((optional))
}

\begin{abstract}
Platinum complexes derived from two families of bidentate funcionalized aroylaminocarbo- $N$-thyoyl prolinates are prepared using mild conditions from prolinates, which are available via 1,3-dipolar cycloadditions. The resulting four coordinated neutral square-planar platinum(II) complexes are very stable and are fully characterized. Their structures are determined by spectroscopic and analytical methods and one of them by single crystal X-ray diffraction analysis. In this pattern, the platinum exhibits distorted square planar geometry, with cis-bond angles ranging from $89.42(2)$ and $94.37(6)^{\circ}$ and trans-bond angles of $176.19(6)$ and $177.08(6)^{\circ}$, respectively. Anti(myco)bacterial and antifungal studies of all these new compounds are carried out under standardized protocols.
\end{abstract}

\section{Introduction}

Apart from catalytic activity, platinum complexes exhibit important pharmacological and biological properties and attract the attention of many synthetic organic chemists. They are very important complexes in the medicinal chemistry area mainly displaying remarkable antitumor activity [1]. However, many other complexes showed antimicrobial, antiviral [2a] antileishmanial, and antitubercular [2b] activities. The modification of the nature of the ligand, anchored to the metal centre, can expand the interaction with microorganisms. For example, this effect is shown for some platinum(II) complexes bearing thiourea-type ligands, which possess interesting biological properties such as anticancer [3], antibacterial/antifungal [4,5,6], antimalarial [7] and antituberculosis [8] activities. Besides, the presence of a pyrrolidine ring is crucial due to the synergistic effects observed in the bioactivity of many compounds [9] and also this heterocycle

[a] Dr. S. Belveren, Dr. S. Poyraz and Prof. H. A. Dondas. Department of Chemistry, Faculty of Pharmacy Institution, Mersin University.

Address 1 Yenisehir, 33169, Mersin, Turkey

E-mail: yakdas25@mersin.edu.tr

[b] Prof. Dr. C. M. Pask

School of Chemistry.

University of Leeds

Leeds LS2 9JT, UK

[c] Prof. Dr. M. Ülger

Department of Pharmaceutical Microbiology, Faculty of Pharmacy, Mersin University

Yenisehir, 33169, Mersin, Turkey

[d] Prof. Dr. J. M. Sansano

E-mail: jmsansano@ua.es

Departamento de Química Orgánica, Instituto de Síntesis Orgánica (ISO) and Centro de Innovación en Química Avanzada (ORFEOCINQA).

University of Alicante, E-03080 Alicante, Spain

Supporting information for this article is given via a link at the end of the document. was the core structure for the construction of biologically important entities [10].

With all these details in mind, we envisaged that the fusion of pyrrolidine and $-\mathrm{C}(\mathrm{O}) \mathrm{NHC}(\mathrm{S})$ - functional moieties into a platinum complex would be an attractive framework to study. In this context, our group has previously reported the synthesis of polysubstituted aroylaminocarbo- $N$-thioyl pyrrolidines and their $\mathrm{Ni}(\mathrm{II}), \mathrm{Pd}(\mathrm{II})$ and $\mathrm{Cu}(\mathrm{II})$ complexes [11]. Also, the presence of the (3-indolyl)methyl group attached to the quaternary carbon (C2 of the pyrrolidine ring) is an important aspect to survey. It was reported that this substituent was a key structural element for the stability of the final rearranged family of succinimides, increasing the biological activity of them [12a].

Here we will detail the synthesis of novel square-planar platinum(II)-complexes of cyclic and bicyclic highly functionalized aroylaminocarbo- $N$-thioyl prolinates from condensation of pyrrolidines with isothiocyanates. The biological activities of prepared compounds against $M$. tuberculosis $H 37 R v$ strain and Staphylococcus aureus (ATCC 25925), Bacillus subtilis (ATCC 6633), Escherichia coli (ATCC 25923), Acinetobacter baumanni (ATCC 02026), and Aeromonas hydrophila (ATCC 95080) standard strains and the anti-fungal activities against Candida albicans ATCC 14053, C. tropicalis ATCC 1369 and C. glabrata ATCC 15126 yeast strains are evaluated too.

\section{Results and Discussion}

Continuing with our research focussed on the structure activity relationship (SAR) of heterocyclic compounds and their metal complexes as bioactive agents, we know that molecules $\mathbf{1}$, which were obtained from 1,3-dipolar cycloaddition reaction between the $\alpha$-amino ester and the maleimide via imine-azomethine ylide in toluene or xylene [12] in $73-95 \%$ yields, resulted to be very attractive since the biological and chemical point of view [10]. In fact, their potential utility of them as bioactive agents has been demonstrated [10]. The bicyclic highly functionalized aroylaminocarbo- $N$-thioyl prolinate ligands $2 \mathrm{a}-\mathrm{e}$ were next synthesized by the condensation of phenyl isothiocyanate and the 
corresponding fused pyrrolidine 1 under refluxing acetonitrile for $48 \mathrm{~h}$ (Scheme 1) [10a]. Immediately, the square-planar platinum(II) complexes 3a-e were prepared form molecules 2 (in $60-75 \%$ yield) by reaction with $\mathrm{K}_{2} \mathrm{PtCl}_{2}$ in acetonitrile- $\mathrm{H}_{2} \mathrm{O}$ at room temperature for 48-72 $\mathrm{h}$ and recrystallized from $\mathrm{DCM}-\mathrm{MeOH}$ as indicated in Scheme 1. The complexes 3a-e were characterized using NMR, IR, microanalyses, mass spectrometry (MALDI-Tof), and HRMS experiments. Despite of their potential crystalline structure none of them gave satisfactory crystals to be analysed by X-ray diffraction.<smiles>[R]C1=C2C(=O)N([R])C(=O)C2([R])NC1([R])Cc1c[nH]c2ccccc12</smiles>

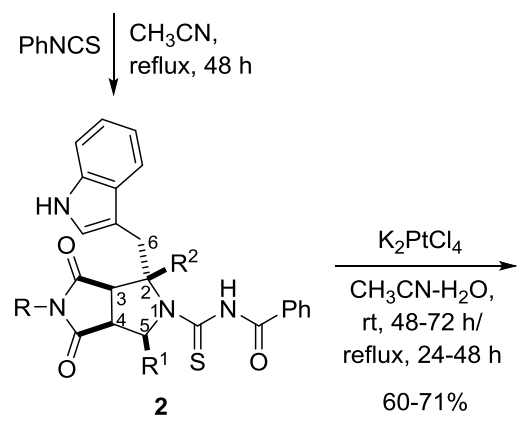

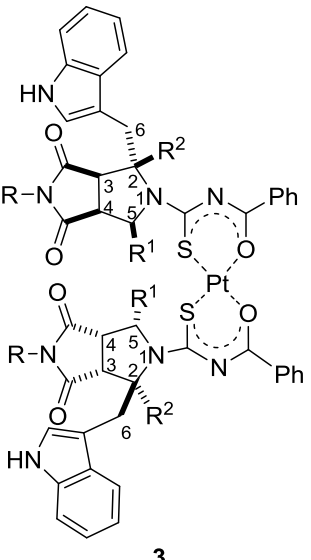

1, 2, 3a. $\mathrm{R}=\mathrm{Ph}, \mathrm{R}^{1}=4$-Chlorophenyl, $\mathrm{R}^{2}=\mathrm{CO}_{2} \mathrm{CH}_{3}$

1, 2, 3b. $\mathrm{R}=\mathrm{CH}_{3}, \mathrm{R}^{1}=4$-Chlorophenyl, $\mathrm{R}^{2}=\mathrm{CO}_{2} \mathrm{C}_{2} \mathrm{H}_{5}$

1, 2, 3c. $\mathrm{R}=\mathrm{CH}_{3}, \mathrm{R}^{1}=4$-Methoxphenyl, $\mathrm{R}^{2}=\mathrm{CO}_{2} \mathrm{C}_{2} \mathrm{H}_{5}$

1, 2, 3d. $R=P h, R^{1}=4-$ Methoxphenyl, $R^{2}=\mathrm{CO}_{2} \mathrm{C}_{2} \mathrm{H}_{5}$

1,2 , 3e. $\mathrm{R}=$ Cyclohexyl, $\mathrm{R}^{1}=4$-Chlorophenyl, $\mathrm{R}^{2}=\mathrm{CO}_{2} \mathrm{C}_{2} \mathrm{H}_{5}$

Scheme 1. Synthetic route for the preparation of platinum(II) complexes 3.

Looking for an appropriate crystalline structure, prolinate derivatives incorporating other different groups at carbon atom number 4 were prepared. It is also known that this structural arrangement showed alternative activity against microorganisms $[12,13]$. In this sense, a new family of series of compounds $\mathbf{4}, \mathbf{5}$ and 6 were designed. Starting compounds endo-prolinates $\mathbf{4}$, were generated by $1,3-\mathrm{DC}$ of the corresponding imino esters and methyl acrylate in $70-89 \%$ yields [12]. They were allowed to react with phenyl isothiocyanate in refluxing acetonitrile to obtain compounds 5a-c in good yields. Following the reaction conditions of the Scheme 1 the synthesis of platinum(II) complexes 6 was successfully achieved in 69-85\% yield (Scheme 2).

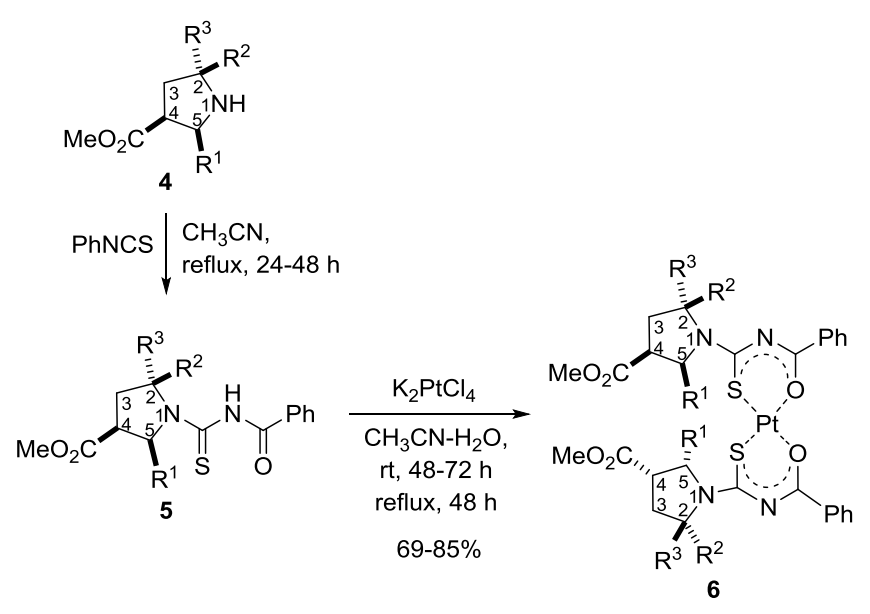

4, 5, 6a. $\mathrm{R}^{1}=$ 2,4-Dimethoxyphenyl, $\mathrm{R}^{2}=\mathrm{CO}_{2} \mathrm{CH}_{3}, \mathrm{R}^{3}=\mathrm{CH}_{2} \mathrm{Ph}$

4, 5, 6b. $\mathrm{R}^{1}=4$-Chlorophenyl, $\mathrm{R}^{2}=\mathrm{CO}_{2} \mathrm{CH}_{3}, \mathrm{R}^{3}=$ indole

4, 5, 6c. $\mathrm{R}^{1}=2,4-$ Dichlorophenyl, $\mathrm{R}^{2}=\mathrm{CO}_{2} \mathrm{CH}_{3}, \mathrm{R}^{3}=\mathrm{CH}_{2} \mathrm{Ph}$

Scheme 2. Synthetic route for the preparation of platinum(II) complexes 6 .

Fortunately, the structure of 6a was confirmed by a single crystal X-ray diffraction studies (Figure 1) [14]. Inspection of the crystallographic data confirmed that the platinum(II) complex $6 a$ was neutral square-planar molecule using the thioureido group/moiety as an efficient stabilizing bidentate ligand. In addition, crystal structural analysis of 6 a corresponded to a meso compound, which is in agreement with the results reported in a previous work [11]. The data of crystal structure of $6 a$, $\left[\mathrm{C}_{31} \mathrm{H}_{31} \mathrm{~N}_{2} \mathrm{O}_{7} \mathrm{~S}\right]_{2} \mathrm{Pt}$ are depicted in Figure. 1, crystallographic data with selected atomic distances and bond angles are listed in Table $1-3$, and refined by a full matrix least squares technique based on $\mathrm{F}^{2}$ using SHELXL2014.

The compound $\mathbf{6 a}$ crystallised as yellow blocks in the $P 1$ space group with one molecule in the asymmetric unit. The molecular structure is shown in Figure 1. The bond lengths for $\mathrm{Pt}(1)-\mathrm{S}(1)=2.2184(7) \AA, \mathrm{Pt}(1)-\mathrm{O}(1)=2.0117(18) \AA, \mathrm{Pt}(1)-\mathrm{S}(2)$ $=2.2346(7) \AA$ and $\mathrm{Pt}(1)-\mathrm{O}(8)=2.0260(18) \AA$ and the angles between $\mathrm{S}(1)-\mathrm{Pt}(1)-\mathrm{S}(2)=89.42(2), \mathrm{O}(1)-\mathrm{Pt}(1)-\mathrm{S}(1)=94.37(6)$, $\mathrm{O}(1)-\mathrm{Pt}(1)-\mathrm{S}(2)=176.19(6), \mathrm{O}(1)-\mathrm{Pt}(1)-\mathrm{O}(8)=84.00(7), \mathrm{O}(8)$ $\mathrm{Pt}(1)-\mathrm{S}(1)=177.08(6)$ and $\mathrm{O}(8)-\mathrm{Pt}(1)-\mathrm{S}(2)=92.24(5)$. The platinum exhibits the already mentioned distorted square planar geometry, with cis bond angles ranging from $89.42(2)$ and $94.37(6)^{\circ}$ and trans bond angles of $176.19(6)$ and $177.08(6)^{\circ}$ (Table 2 and 3 ). Minor disorder was observed around one of the phenyl rings, which was modelled in a 60:40 ratio, with thermal ellipsoids restrained using a rigid bond restraint. There is no evidence of hydrogen bonding or $\pi-\pi$ interactions in the solid state.

Table 1: Crystallographic data for $\mathbf{6 a}$.

\begin{tabular}{|l|l|}
\hline Empirical formula & $\mathrm{C}_{62} \mathrm{H}_{62} \mathrm{~N}_{4} \mathrm{O}_{14} \mathrm{PtS}$ \\
\hline Formula weight & 1346.36 \\
\hline Temperature/K & $121(1)$ \\
\hline Crystal system & triclinic \\
\hline Space group & $\mathrm{P}-1$ \\
\hline $\mathrm{a} / \AA$ & $14.3323(2)$ \\
\hline $\mathrm{b} / \AA$ & $14.3931(2)$ \\
\hline $\mathrm{c} / \AA$ & $15.4532(2)$ \\
\hline $\mathrm{\alpha} /{ }^{\circ}$ & $91.1570(10)$ \\
\hline$\beta /{ }^{\circ}$ & $105.0220(10)$ \\
\hline $\mathrm{\gamma} /{ }^{\circ}$ & $90.4890(10)$ \\
\hline
\end{tabular}




\begin{tabular}{|c|c|}
\hline Volume/ $/ \AA^{3}$ & $3077.90(7)$ \\
\hline Z & 2 \\
\hline$\rho_{\text {calc }} \mathrm{g} / \mathrm{cm}^{3}$ & 1.453 \\
\hline$\mu / \mathrm{mm}^{-1}$ & 2.414 \\
\hline$F(000)$ & 1368.0 \\
\hline Crystal size $/ \mathrm{mm}^{3}$ & $0.16 \times 0.11 \times 0.06$ \\
\hline Radiation & $\mathrm{Mo} \mathrm{K}_{\alpha}(\lambda=0.71073)$ \\
\hline $\begin{array}{l}2 \Theta \text { range for data } \\
\text { collection } /{ }^{\circ}\end{array}$ & 6.092 to 62.266 \\
\hline Index ranges & $\begin{array}{l}-20 \leq h \leq 20,-20 \leq k \leq 20,-21 \\
\leq 1 \leq 22\end{array}$ \\
\hline Reflections collected & 54186 \\
\hline Independent reflections & $\begin{array}{l}17532\left[R_{\text {int }}=0.0403, R_{\text {sigma }}=\right. \\
0.0505]\end{array}$ \\
\hline Data/restraints/parameters & $17532 / 63 / 774$ \\
\hline Goodness-of-fit on $\mathrm{F}^{2}$ & 1.039 \\
\hline Final $R$ indexes $[\mid>=2 \sigma(I)]$ & $R_{1}=0.0358, w R_{2}=0.0668$ \\
\hline Final $\mathrm{R}$ indexes [all data] & $\mathrm{R}_{1}=0.0509, \mathrm{wR}_{2}=0.0728$ \\
\hline Largest diff. peak/hole / e $\AA^{-3}$ & $1.57 /-0.78$ \\
\hline
\end{tabular}

Table 2: Selected bond lengths for $6 \mathbf{a}$.

\begin{tabular}{|l|l|l|}
\hline Atom & Atom & Length/A \\
\hline Pt1 & S1 & $2.2184(7)$ \\
\hline Pt1 & O1 & $2.0117(18)$ \\
\hline Pt1 & S2 & $2.2346(7)$ \\
\hline Pt1 & O8 & $2.0260(18)$ \\
\hline
\end{tabular}

Table 3: Selected bond angles for $\mathbf{6 a}$.

\begin{tabular}{|l|l|l|l|}
\hline Atom & Atom & Atom & \multicolumn{1}{|c|}{ Angle $^{\circ}$} \\
\hline S1 & Pt1 & S2 & $89.42(2)$ \\
\hline O1 & Pt1 & S1 & $94.37(6)$ \\
\hline O1 & Pt1 & S2 & $176.19(6)$ \\
\hline O1 & Pt1 & O8 & $84.00(7)$ \\
\hline O8 & Pt1 & S1 & $177.08(6)$ \\
\hline O8 & Pt1 & S2 & $92.24(5)$ \\
\hline
\end{tabular}

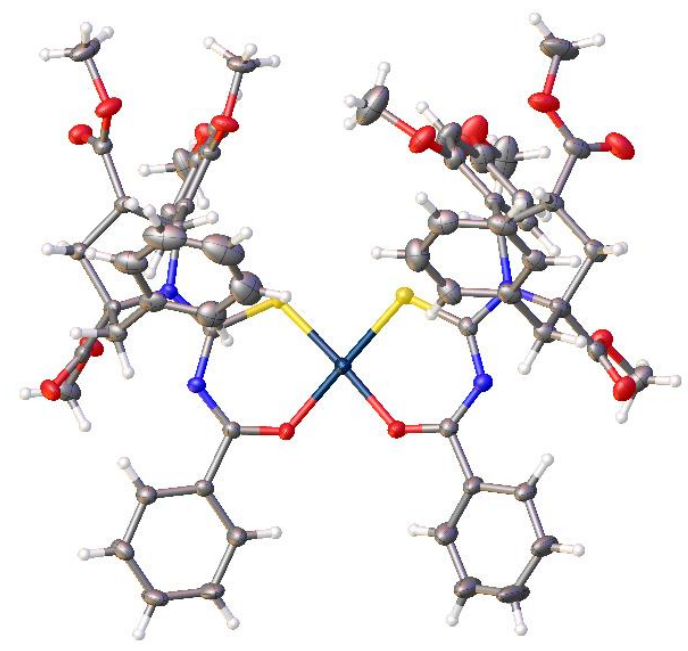

Figure 1. Crystal structure corresponding to compound $6 \mathbf{6 a}$ [14].

Antibacterial activity. Stock solutions were prepared by dissolving the tested compounds in DMSO and then diluting in Mueller-Hinton broth and the test medium were prepared at concentrations of $500,250,125,62.5,31.25,15.62,7.8,3.9$ and $1.9 \mu \mathrm{g} / \mathrm{mL}$. The minimum inhibitory concentrations (MIC) values was determined by broth dilution in duplicate as recommended by the Clinical Laboratory Standards Institute [15]. To ensure that the solvents had no effect on microbial growth, a control test was performed containing inoculated broth supplemented with DMSO which used for the test compounds 1a, 2a, 3a-e and 6a-c. The MIC values of the compounds were investigated against standard bacterial strains, obtained from the Refik Saydam Hıfzısıhha Institute, Ankara, Turkey. The antibacterial activity were assessed against two Gram (+) bacteria Staphylococcus aureus (ATCC 25925), Bacillus subtilis (ATCC 6633) and three Gram (-) bacteria Escherichia coli (ATCC 25923), Acinetobacter baumannii (ATCC 02026), and Aeromonas hydrophila (ATCC 95080). The MIC values for the compounds ( $\mathbf{1 a}$ and $\mathbf{2 a}$ ) were found in the range of $15,62-125 \mu \mathrm{g} / \mathrm{ml}$ and for the platinium complexes (3a-e) and (6ac) in the range of $31,25-500 \mu \mathrm{g} / \mathrm{mL}$. The control, ampicillin, showed activity with a range of $0.9-31.25 \mu \mathrm{g} / \mathrm{mL}$ against the tested bacteria as given in Table 1 . The ligand molecule $\mathbf{2 a}$ revealed the highest activities with the MIC values of $15.62 \mu \mathrm{g} / \mathrm{mL}$ when tested against Aeromonas hydrophila (ATCC 95080).

Anti-tuberculosis (TB) activity. Anti-TB activity of the tested compounds was performed according to literature method utilizing Microplate Alamar Blue assay [16]. The anti-tuberculosis activity of the novel target compounds (1a, 2a, 3a-3e, 6a-6c) were tested against $M$. tuberculosis H37Rv strain and measured by means of the minimum inhibitory concentrations (MIC) values $(\mu \mathrm{g} / \mathrm{mL})$. Thus Streptomycin (Sigma S6501), Izoniazid (INH) (Sigma 13377), Rifampicin (Sigma R3501), Ethambutol (EMB) (Sigma E4630) were used as standard known active reference drugs (Table 1). The bioactivity of the target compounds showed activity, in the range of $7.81-62.5 \mu \mathrm{g} / \mathrm{mL}$ (Table 2). The ligand molecule 2a bearing phenyl, 4-chlorophenyl and methyl ester moieties revealed the highest activities with the MIC values of $7.81 \mu \mathrm{g} / \mathrm{mL}$ whereas the rest of molecules 1a, 3a-3e, 6a-c showed moderate anti-TB activities in $62.5 \mu \mathrm{g} / \mathrm{mL}$ MIC values against $\mathrm{M}$. tuberculosis H37Rv strain. Although biological target/ the mode of action of these novel molecules is unknown at the moment it seems that some molecules needs further alteration to increase their activity by modification of some part of the structure.

Anti-fungal activity. The anti-fungal activities of the target compounds (1a, 2a, 3a-3e, 6a-6c) were tested against Candida albicans ATCC 14053, C. tropicalis ATCC 1369 and C. glabrata ATCC 15126 yeast strains according to the NCCLS standard document M27-A2 [17] using the microdilution broth procedure $[18,19]$ and measured by means of MIC values $(\mu \mathrm{g} / \mathrm{mL})$. Candida strains were obtained from Refik Saydam Hifzıssıhha Institute, Ankara, Turkey. Antifungal activities were performed in RPMI 1640 Medium (Sigma, R6504) which buffered to $\mathrm{pH} 7.0$ with 0.165 M 3-(N-morpholino)-propanesulfonic acid (MOPS, Sigma, M1254) as outlined in document. Stock solutions of the tested compounds and reference antifungal agent were prepared in DMSO at a concentration of $1000 \mu \mathrm{g} / \mathrm{mL}$. Standard strains is diluted by a 1:100 dilution followed by a 1:20 dilution of the stock suspension with RPMI 1640 medium which were then filtered via a $0.22 \mu \mathrm{m}$ membrane. The fluconazole (Sigma, F8929) was used as standard known active reference drug and showed activity with a range of $3.90-31.25 \mu \mathrm{g} / \mathrm{ml}$ when tested against the indicated yeast. The novel tested molecules (1a, 2a, 3a-3e, 6a-c) showed moderate anti-fungal activities in the range of $125-250$ $\mu \mathrm{g} / \mathrm{mL}$ MIC values (Table 2). 
Table 1 Antibacterial and anti-tuberculosis activities $(\mu \mathrm{g} / \mathrm{mL})$

\begin{tabular}{|c|c|c|c|c|c|c|c|c|}
\hline & $\begin{array}{l}\text { Staphylococcus aureus } \\
\text { (ATCC 25925) }\end{array}$ & $\begin{array}{l}\text { Escherichia coli } \\
\text { (ATCC 25923) }\end{array}$ & $\begin{array}{l}\text { Acinetobacter } \\
\text { baumannii } \\
\text { 02026) }\end{array}$ & (ATCC & $\begin{array}{l}\text { Bacillus subtilis } \\
\text { (ATCC 6633) }\end{array}$ & $\begin{array}{l}\text { Aeromonas } \\
\text { hydrophila } \\
95080)\end{array}$ & (ATCC & $\begin{array}{l}\text { M. tuberculosis } \\
\text { H37RV }\end{array}$ \\
\hline $1 a$ & $62,5 \mu \mathrm{g} / \mathrm{mL}$ & $62,5 \mu \mathrm{g} / \mathrm{mL}$ & $31,25 \mu \mathrm{g} / \mathrm{mL}$ & & $125 \mu \mathrm{g} / \mathrm{mL}$ & $31,25 \mu \mathrm{g} / \mathrm{mL}$ & & $62,5 \mu \mathrm{g} / \mathrm{mL}$ \\
\hline $2 a$ & $62,5 \mu \mathrm{g} / \mathrm{mL}$ & $62,5 \mu \mathrm{g} / \mathrm{mL}$ & $31,25 \mu \mathrm{g} / \mathrm{mL}$ & & $125 \mu \mathrm{g} / \mathrm{mL}$ & $15,62 \mu \mathrm{g} / \mathrm{mL}$ & & $7.81 \mu \mathrm{g} / \mathrm{mL}$ \\
\hline $3 a$ & $62,5 \mu \mathrm{g} / \mathrm{mL}$ & $62,5 \mu \mathrm{g} / \mathrm{mL}$ & $31,25 \mu \mathrm{g} / \mathrm{mL}$ & & $125 \mu \mathrm{g} / \mathrm{mL}$ & $31,25 \mu \mathrm{g} / \mathrm{mL}$ & & $62,5 \mu \mathrm{g} / \mathrm{mL}$ \\
\hline $3 b$ & $250 \mu \mathrm{g} / \mathrm{mL}$ & $250 \mu \mathrm{g} / \mathrm{mL}$ & $125 \mu \mathrm{g} / \mathrm{mL}$ & & $250 \mu \mathrm{g} / \mathrm{mL}$ & $500 \mu \mathrm{g} / \mathrm{mL}$ & & $62,5 \mu \mathrm{g} / \mathrm{mL}$ \\
\hline $3 c$ & $62,5 \mu \mathrm{g} / \mathrm{mL}$ & $62,5 \mu \mathrm{g} / \mathrm{mL}$ & $31,25 \mu \mathrm{g} / \mathrm{mL}$ & & $125 \mu \mathrm{g} / \mathrm{mL}$ & $31,25 \mu \mathrm{g} / \mathrm{mL}$ & & $62,5 \mu \mathrm{g} / \mathrm{mL}$ \\
\hline $3 d$ & $500 \mu \mathrm{g} / \mathrm{mL}$ & $250 \mu \mathrm{g} / \mathrm{mL}$ & $125 \mu \mathrm{g} / \mathrm{mL}$ & & $250 \mu \mathrm{g} / \mathrm{mL}$ & $62,5 \mu \mathrm{g} / \mathrm{mL}$ & & $62,5 \mu \mathrm{g} / \mathrm{mL}$ \\
\hline $3 e$ & $250 \mu \mathrm{g} / \mathrm{mL}$ & $250 \mu \mathrm{g} / \mathrm{mL}$ & $125 \mu \mathrm{g} / \mathrm{mL}$ & & $62,5 \mu \mathrm{g} / \mathrm{mL}$ & $62,5 \mu \mathrm{g} / \mathrm{mL}$ & & $62,5 \mu \mathrm{g} / \mathrm{mL}$ \\
\hline $6 a$ & $250 \mu \mathrm{g} / \mathrm{mL}$ & $250 \mu \mathrm{g} / \mathrm{mL}$ & $125 \mu \mathrm{g} / \mathrm{mL}$ & & $250 \mu \mathrm{g} / \mathrm{mL}$ & $500 \mu \mathrm{g} / \mathrm{mL}$ & & $62,5 \mu \mathrm{g} / \mathrm{mL}$ \\
\hline $6 b$ & $62,5 \mu \mathrm{g} / \mathrm{mL}$ & $62,5 \mu \mathrm{g} / \mathrm{mL}$ & $31,25 \mu \mathrm{g} / \mathrm{mL}$ & & $125 \mu \mathrm{g} / \mathrm{mL}$ & $31,25 \mu \mathrm{g} / \mathrm{mL}$ & & $62,5 \mu \mathrm{g} / \mathrm{mL}$ \\
\hline $6 c$ & $250 \mu \mathrm{g} / \mathrm{mL}$ & $250 \mu \mathrm{g} / \mathrm{mL}$ & $125 \mu \mathrm{g} / \mathrm{mL}$ & & $250 \mu \mathrm{g} / \mathrm{mL}$ & $125 \mu \mathrm{g} / \mathrm{mL}$ & & $62,5 \mu \mathrm{g} / \mathrm{mL}$ \\
\hline Ampicillin & 32.25 & 15.62 & 125 & & 0.9 & 31.25 & & \\
\hline Streptomycin & & & & & & & & $0,06 \mu \mathrm{g} / \mathrm{mL}$ \\
\hline Izoniazid & & & & & & & & $0,12 \mu \mathrm{g} / \mathrm{mL}$ \\
\hline Rifampicin & & & & & & & & $0,97 \mu \mathrm{g} / \mathrm{mL}$ \\
\hline Etambutol & & & & & & & & $1,95 \mu \mathrm{g} / \mathrm{mL}$ \\
\hline
\end{tabular}

Table 2 Anti-fungal activity $(\mu \mathrm{g} / \mathrm{ml})$

\begin{tabular}{lccc}
\hline & $\begin{array}{l}\text { Candida albicans } \\
\text { ATCC } 14053\end{array}$ & $\begin{array}{l}\text { Candida } \\
\text { tropicalis ATCC } \\
1369\end{array}$ & $\begin{array}{l}\text { Candida } \\
\text { glabrata ATCC } \\
15126\end{array}$ \\
\hline 1a & $125 \mu \mathrm{g} / \mathrm{mL}$ & $125 \mu \mathrm{g} / \mathrm{mL}$ & $125 \mu \mathrm{g} / \mathrm{mL}$ \\
2a & $125 \mu \mathrm{g} / \mathrm{mL}$ & $250 \mu \mathrm{g} / \mathrm{mL}$ & $125 \mu \mathrm{g} / \mathrm{mL}$ \\
3a & $250 \mu \mathrm{g} / \mathrm{mL}$ & $125 \mu \mathrm{g} / \mathrm{mL}$ & $250 \mu \mathrm{g} / \mathrm{mL}$ \\
3b & $125 \mu \mathrm{g} / \mathrm{mL}$ & $125 \mu \mathrm{g} / \mathrm{mL}$ & $125 \mu \mathrm{g} / \mathrm{mL}$ \\
3c & $250 \mu \mathrm{g} / \mathrm{mL}$ & $250 \mu \mathrm{g} / \mathrm{mL}$ & $125 \mu \mathrm{g} / \mathrm{mL}$ \\
3d & $125 \mu \mathrm{g} / \mathrm{mL}$ & $125 \mu \mathrm{g} / \mathrm{mL}$ & $250 \mu \mathrm{g} / \mathrm{mL}$ \\
3e & $250 \mu \mathrm{g} / \mathrm{mL}$ & $250 \mu \mathrm{g} / \mathrm{mL}$ & $125 \mu \mathrm{g} / \mathrm{mL}$ \\
6a & $125 \mu \mathrm{g} / \mathrm{mL}$ & $125 \mu \mathrm{g} / \mathrm{mL}$ & $125 \mu \mathrm{g} / \mathrm{mL}$ \\
6b & $125 \mu \mathrm{g} / \mathrm{mL}$ & $125 \mu \mathrm{g} / \mathrm{mL}$ & $125 \mu \mathrm{g} / \mathrm{mL}$ \\
6c & $125 \mu \mathrm{g} / \mathrm{mL}$ & $125 \mu \mathrm{g} / \mathrm{mL}$ & $250 \mu \mathrm{g} / \mathrm{mL}$ \\
Fluconazole & $31.25 \mu \mathrm{g} / \mathrm{mL}$ & $15.62 \mu \mathrm{g} / \mathrm{mL}$ & $3.90 \mu \mathrm{g} / \mathrm{mL}$ \\
\hline
\end{tabular}

\section{Conclusions}

The $N$-benzoylthiourea framework possessing pharmacophores containing prolinate units resulted to be a very strong bidentate ligand towards the platinum atom affording very stable planar dimeric entities. These series of highly pure complexes were isolated in good yields. Antibacterial, antituberculosis, and antifungal studies of all these new compounds revealed that molecule 2 a possesed the highest activity with the MIC values of $15.62 \mu \mathrm{g} / \mathrm{mL}$ when tested against Aeromonas hydrophila. This level is much more effective than the own shown by Ampicillin. In addition, the same molecule $\mathbf{2} \mathbf{a}$ exhibited the highest activities with the MIC values of $7.81 \mu \mathrm{g} / \mathrm{mL}$ against M. tuberculosis H37Rv strain. All families of derivatives were tested as antigungals showing moderate activities in the range of $125-250 \mu \mathrm{g} / \mathrm{mL}$ MIC values, which are very high with respect to the effective fluconazole doses. At the moment, the biological properties and the mode of action for corresponding molecules is unknown, but we are currently modifying some substituents of the skeleton in order to increase their activities text of the article should appear here with headings as appropriate.

\section{Experimental Section}

General procedure for the synthesis of aminocarbothiolpyrrolidines (2 and 5): To a solution of the corresponding pyrrolidine $(1.2 \mathrm{mmol})$ in dry acetonitrile $(25 \mathrm{~mL})$ was added dropwise benzoyl isothiocyanate $(0.213$ $\mathrm{mL}, 1.3 \mathrm{mmol}$ ) in dry acetonitrile $(15 \mathrm{~mL})$. The resulting solution was stirred at room temperature for $24-48 \mathrm{~h}$ or reflux $48 \mathrm{~h}$. After completion of the reaction by monitoring TLC, the solvent removed and purified by flash chromatography.

General procedure for the synthesis of platinium complexes (3a-e, 6a-c): In a flask containing the corresponding aminocarbothiolpyrrolidine $(2 \mathrm{mmol})$ in acetonitrile $(20 \mathrm{~mL}), \mathrm{K}_{2} \mathrm{PtCl}_{4}(1 \mathrm{mmol})$ in water $(10 \mathrm{~mL})$ was added and the resulting solution was stirred at room temperature $48-72 \mathrm{~h}$ or under reflux for 24-48 $\mathrm{h}$. The solvent was evaporated and the crude mixture was analysed by ${ }^{1} \mathrm{H}$ NMR and then crystallised in appropriate solvent to give a yellow solid.

X-Ray Crystallographic Analysis of 6a: Measurements were carried out at $120 \mathrm{~K}$ on an Agilent SuperNova diffractometer equipped with an Atlas CCD detector and connected to an Oxford Cryostream low temperature device using mirror monochromated $/ \mathrm{Mo} \mathrm{K}_{\alpha}$ radiation $(\lambda=0.7107 \AA$ ) from a Microfocus $X$-ray source. The structure was solved by intrinsic phasing using SHELXT [20] and refined by a full matrix least squares technique based on $\mathrm{F}^{2}$ using SHELXL2014 [21].

\section{Acknowledgments}

This work is a part of Samet Belveren's ongoing PhD thesis granted by Mersin University (Project no. BAP-SBE TEB(SB) 
2017-2-TP3-2564). We gratefully acknowledge financial support from Mersin University and the Spanish Ministerio de Economía y Competitividad (MINECO) (projects CTQ2013-43446-P and CTQ2014-51912-REDC), the Spanish Ministerio de Economía, Industria y Competitividad, Agencia Estatal de Investigación (AEI) and Fondo Europeo de Desarrollo Regional (FEDER, EU) (projects CTQ2016-76782-P and CTQ2016-81797-REDC), the Generalitat Valenciana (PROMETEOII/2014/017), University of Alicante and Mersin University (Project. MEU-2017-COL-01007M150D).
Keywords: platinum complexes-aminocarbothiol-antibacterialantifungal-antituberculosis 


\section{Table of Contents}

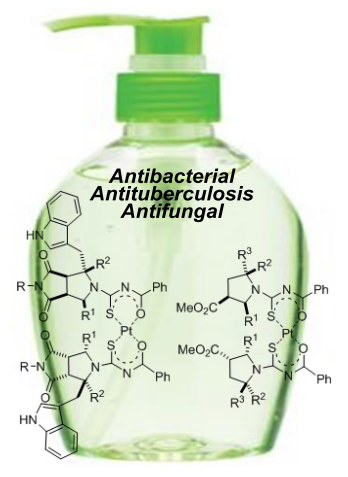

${ }^{*}$ Antimicrobial platinum complexes

\section{References}

[1] a) L. Bai, C. Gao, Q. Liu, C. Yu, Z. Zhang, L. Cai, B. Yang, Y. Qian, J. Yang, X. Liao, Eur. J. Med. Chem. 140 (2017) 349-382;

b) L. Cai, C. Yu, L. Ba, Q. Liu, Y. Qian, B. Yang, C. Gao, Appl. Organometal. Chem. 32 (2018) 1-17;

c) A. Najjar, N. Rajabi, R. Karaman, Curr. Pharm. Design 23 (2017) 2366-2376;

d) K. Mitra, Dalton Trans. 45 (2016) 19157-19171.

e) Z. Li, J. Zhou, Y. Gan, Y. Yin., W. Zhang, J. Yang, Y. Tang, Y. Dai, J. Inorg Biochem. 197 (2019) 110701-110709.

[2] a) M. Cavicchioli, A.C. Massabni, T.A. Heinrich, C.M. Costa-Neto, E.P. Abrão, B.A. Fonseca, E.E. Castellano, P.P. Corbi, W.R. Lustri, C.Q. Leite, J. Inorg. Biochem. 104 (2010) 533-540;

b) A.M.L. Carmo, F.M.C. Silva, P.A. Machado, A.P.S. Fontes, F.R. Pavan, C.Q.F. Leite, S.R. de A. Leite, E.S. Coimbra, A.D. Da Silva, Biomed. Pharmacotherapy 65 (2011) 204-209.

[3] S. Mihai, M. Negoiu, Rev. Chim. 63 (2012) 697-702.

[4] a) A.M. Mansour, Appl. Organometal. Chem. 32 (2018) 1-8;

b) S. Jambi, J. Mol. Liquids 262 (2018) 237-247;

c) U. Solmaz, I. Gumus, G. Binzet, O. Celik, G.K. Balci, A. Dogen, H. Arslan, J. Coord. Chem. 71 (2018) 200-218;

d) N. Manav, A.K. Mishra, N.K. Kaushik, Spectrochim. Acta Part A: Mol. Biomol. Spectr. 65 (2006) 32-35;

e) M.M. Ahmed, Appl. Organometal. Chem. 32 (2018) e3928, doi:10.1002/aoc.3928.

[5] R. del Campo, J.J. Criado, E. García, M.R. Hermosa, A. Jiménez-Sánchez, J.L. Manzano, E. Monte, E. RodríguezFernández, F. Sanz, J. Inorg. Biochem. 89 (2002) 74-82.

[6] a) A.M. Plutín, A. Álvarez, R. Mocelo, R. Ramos, E.E. Castellano, M.M. da Silva, L. Colina-Vegas, F.R. Pavan, A.A. Batista, Inorg. Chem. Commun. 63 (2016) 74-80;

b) L. Shadap, S. Diamai, J.L. Tyagi, K. M. Poluri, W. Kaminsky, M.R. Kollipara, J. Organomet. Chem. 897 (2019) 207-216.

[7] T.J. Egan, K.R. Koch, P.L. Swan, C. Clarkson, D.A. Van Schalkwyk, P.J. Smith, J. Med. Chem. 47 (2004) $2926-2934$.

[8] R. Arancibia, C. Quintana, C. Biot, M.E. Medina, S. Carrère-Kremer, L. Kremer, A.H. Klahn, Inorg. Chem. Commun. 55 (2015) 139-142.

[9] a) H.A. Dondas, M.G. Retamosa, J.M. Sansano, Synthesis 49 (2017) 2819-2851;

b) D. O'Hagan, Nat. Prod. Rep. 17 (2000) 435-446.

[10] a) S. Belveren, H.A. Dondas, M. Ulger, S. Poyraz, E. García-Mingüens, M. Ferrandiz-Saperas, J.M. Sansano, Tetrahedron 73 (2017) 6718-6727;

b) C.A. Van Huis, C.F. Bigge, A. Casimiro-Garcia, W.L. Cody, D.A. Dudley, K.J. Filipski, R.J. Heemstra, J.T. Kohrt, L.S. Narasimhan, R.P. Schaum, E. Zhang, J.W. Bryant, S. Haarer, N. Janiczek, R.J. Leadley Jr, T. McClanahan, J. T. Peterson, K.M. Welch, J.J. Edmunds, Biol. Drug Des. 69 (2007) 444-450;

c) H.A. Dondas, R. Grigg, C. Kilner, Tetrahedron 2003, 59, 8481-8487; 
d) S. Poyraz, S. Belveren, M. Ülger, E. Şahin, H.A. Dondas, Monats Chem. Chem. Month. 148 (2017) 2173-2182;

e) H.A. Dondas, J. Duraisingham, R. Grigg, W. S. MacLaclan, D.T. MacPherson, M. Thornton-Pett, V. Sridharan, S. Suganthan, Tetrahedron 56 (2000) 4063-4070.

[11] Y. Nural, R. Kilincarslan, H.A. Dondas, B. Cetinkaya, M.S. Serin, R. Grigg, T. Ince, C. Kilner, Polyhedron 28 (2009) 2847-2854.

[12] a) S. Belveren, O. Larrañaga, S. Poyraz, H.A. Dondas, M. Ülger, E. Şahin, M. Ferrándiz-Saperas, J.M. Sansano, M.G. Retamosa, A. de Cózar, Synthesis 51 (2019) 1565-1577;

b) H.A. Dondas, O. Altınbas, Heterocycl. Commun. 10 (2004) 167-173.

[13] a) I. Arrastia, A. Arrieta, F.P. Cossío, Eur. J. Org. Chem. (2018) 5889-5904;

b) C. Nájera, J.M. Sansano, Actualité Chim. 370 (2013) 28-30;

c) C. Nájera, J.M. Sansano, Org Biomol Chem. 7 (2009) 4567-4681.

[14] The corresponding deposition number assigned by the Cambridge Crystallographic Data Centre was CCDC 1916235.

[15] a) J.C. Palomino, F. Portaels, Eur. J. Clin. Microbiol. Infect. Dis. 18 (1999) 380-383;

b) National Committee for Clinical Laboratory Standards. Susceptibility Testing of Mycobacteria, Nocardia, and Other Aerobic Actinomycetes: Approved Standard NCCLS Document M24-a. NCCLS. 2003 (Wayne, Pennsylvania);

c) National Committee for Clinical Laboratory Standards. Tentativ Standard-Second Edition NCCLS Document M24t. Susceptibilitiy Testing of Mycobacteria, Nocardia and other aerobic Actinomycetes. 2002. Pensylvania USA.

[16] S. Poyraz, N. Canacankatan, S. Belveren, D. Yetkin, K. Kibar, M. Ulger, J.M. Sansano, N.D. Ozcelik, S.N. Y1lmaz, H.A. Dondas. Monatsh. Chem.- Chem.Month, 149 (2018) 2253-2263.

[17] NCCLS. Reference Method for Broth Dilution Antifungal Susceptibility Testing of Yeasts; Approved Standard-Second Edition. NCCLS document M27-A2 (ISBN 1-56238-469-4). NCCLS, 940 West Valley Road, Suite 1400, Wayne, Pennsylvania 19087-1898 USA, 2002.

[18] M. Sonmez, M. Çelebi, I. Berber, Eur. J. Med. Chem. 45 (2010) 1935-1940.

[19] N. U. Güzeldemirci, O. Küçükbasmacı. Eur. J. Med. Chem. 45 (2010) 63-68.

[20] G.M. Sheldrick, Acta Crystallogr. A 71 (2015) 3-8.

[21] G.M. Sheldrick, Acta Crystallogr. C 71 (2015) 3-8. 